\title{
Appendix: methodology
}

Because of the conspiratorial, covert nature of the IRA, the regular collecting, ordering, and filing of documents has been out of the question. As little as possible was written and much was destroyed as soon as possible.

J. Bowyer Bell ${ }^{1}$

Accounts collected through intensive interviews and oral histories are an important source for understanding human behaviour.

Robert W. White ${ }^{2}$

\section{Introduction}

This book is a culmination of research into the ideology and motivations of Irish republicans who exist beyond the mainstream status quo. The aim of the research, which began in 2011, was to provide an analysis of the motivations, strategies and aspirations of what is commonly referred to as 'dissident republicanism'. With notable exceptions, including the work of Robert W. White and J. Bowyer Bell, literature in this field has been dominated by 'terrorism studies' or 'counter-terrorism studies'. This research was fundamentally different in nature from that approach, seeking to provide a theoretical and empirical understanding of non-mainstream republicans, drawing extensively on personal testimonies with republican activists (ninety in-depth qualitative interviews were conducted). While existing literature has detailed the various 'breaking points' at which the different 'dissident' organisations emerged, a significant aim of this book is to provide an insight into the experience of individuals within the Provisional Movement at these pivotal points (based on their testimonies) in order to produce a more nuanced analysis of the ideology and varied strands within radical republicanism.

\section{Qualitative interviews}

Interviews were conducted with all the 'dissident' organisations and were representative of gender and geographical location. The youngest interviewee was 
a nineteen-year-old Na Fianna Éireann member in Dublin and the oldest was ninety-three-year-old Billy McKee in Belfast. Interviews were conducted in the North and South of Ireland and interview locations included Belfast, Dublin, Galway, Tyrone, Armagh, Tralee, Cahersiveen, Mayo, Lurgan, Killarney, Kilkenny, Derry, Portadown, Strabane, Monaghan, Newry, Omagh, Skerries, Drogheda and Dungiven; as well as Nottingham, Birmingham and Stafford in England. Interviews were conducted with individuals at various levels in organisations, from those in leadership to local cumainn members; as well as prominent republicans and individuals who are less well known. Interviewees include individuals who are unemployed as well as those in a range of jobs, including the following: solicitors, a barrister, a taxi driver in Belfast, a retired psychiatric nurse, farmers in Galway and Tralee, elected councillors in the North and South, a teacher, a caretaker in the Catholic Church, a grave digger, construction workers, and graduates from Queen's University Belfast and Trinity College Dublin, among many others.

Significantly, the study included interviews with individuals who joined the Republican Movement at different points in time, reflecting a range of motivations and outlooks. Interviews were also conducted with a large body of 'independents', as it emerged throughout the research that independents form a significant section of the non-mainstream republican population. Interviews were also conducted with republican prisoners in Maghaberry prison, which is located outside Lisburn in the North of Ireland. In August 2013 the author undertook focus groups in Derry which included members of the 32CSM and independent republicans. The focus groups proved valuable to the research, demonstrating an exchange of views between members of different republican groups.

The study has undertaken numerous interviews with individuals who are currently labelled 'dissident republican' who have previously occupied senior leadership positions either in Sinn Féin or in the Provisional IRA; a notable example being the late Tony Catney, who occupied a position on the Northern Command of the Provisional IRA before departing the Provisional Movement and becoming a prominent member of the 1916 Societies. A further highprofile example is Kevin Hannaway, a former adjutant-general of the Provisional IRA; Hannaway's father Liam Hannaway was also a senior member of the Provisional IRA. Kevin Hannaway is now an independent republican in Belfast. Interviewees also include individuals who held leadership positions in Sinn Féin or the wider Republican Movement prior to 1986 such as Lita Campbell in RSF in Dublin (originally from Cork), Phil O'Donoghue, the honorary president of the 32CSM (who lives in Kilkenny), and Richard Behal, an independent republican in Killarney.

This book has benefited from the author's attendance at numerous republican meetings and events, which has provided insight into the organisational and 
social culture of radical republicanism. The author attended multiple republican commemorations, geographically spanning the North and South of Ireland; as well as the unveiling of a republican monument in Lurgan by RSF in May 2016. Additionally, the author attended seminars and Ard Fheiseanna of the various radical republican organisations. On 16 October 2013 the author attended the 'Burning of Long Kesh' seminar in Tyrone which was organised by the 1916 Societies and which included several prominent independent republican speakers. A further event which proved significant to the research was an internal mock debate which the 1916 Societies held in the Suffolk area of West Belfast in 2012. During the debate members of the Society assumed opposing sides regarding calls for a border poll, with Tony Catney arguing the Provisional Sinn Féin position. Finally, the author attended public events organised by éirígí in Belfast on the financial cuts in the North of Ireland as well as anti-internment marches in Belfast over a number of years which have encompassed members of all republican groups.

A key strength of this study is the range of interviews conducted. The large body of material amassed has enabled the extraction of themes which are of significance to radical republicanism. This work is based on the fundamental premise that the best way to understand the motivations and tactics of radical republicanism is to speak to the individuals and organisations involved. As documented by Robert W. White, 'accounts from activists offer rich, detailed information on the motives and social processes that promote recruitment and sustain activism' ${ }^{3}$ This research was conducted after the establishment of trust between the author and the interviewees for this book. The establishment of contacts, gatekeepers and potential interviewees took several years of trustbuilding; several interviews were gained through 'snowballing'. ${ }^{4}$ Initial contacts were established through the author's attendance at republican events, as well as through the offices of radical republican groups in Belfast and Dublin.

\section{Project problem}

This research became a funded project titled 'A Theoretical and Empirical Assessment of the Membership, Strategies and Tactics of Dissident Irish Republicans' in 2012 when, subsequent to forming a research team (with Professor Jonathan Tonge at Liverpool University as the Principal Investigator; PI) the project gained funding from the Economic and Social Research Council. In August 2014 a serious problem arose concerning the research project and a book based on this research would not be complete without detailed comment. In August 2014 the author (also the researcher) first became aware of an impact statement which had been written by the PI as part of the funding application. In the impact statement the PI had written that 'the information yielded by this research project extends well beyond the academic community to [points 1-8] 
... the Secretary of State for Northern Ireland, the PSNI (and security services), An Garda Síochána and MI5', among others listed. The PI subsequently stated 'The impacts listed at 1-8 will be achieved via the following: ... d. Ongoing briefings as required to the organisations listed in 1-8 above. ${ }^{5}$ This issue came to light when the project's funding body posted the project's 'impact statement' on its website in a bid to showcase the projects which it was funding.

This impact statement was false and completely at odds with the nature and aims of the project. Until it appeared in the public domain, the author had not been aware of this impact statement which had been submitted by the PI to the ESRC. As is standard practice, such documentation does not come to the 'researcher', but is exchanged between the PI, co-investigators and the funding body. The application is also sent out for peer review. I find it imperative to state that, in my view, academic research should never be an information-gathering exercise for the security services or the state. As the researcher (and the person who initiated this research), it was distressing to learn of the contents of the impact statement, as this project was conducted to high ethical standards and in fact the project team had put in place multiple measures to protect interviewees, the research and the project team. The author was highly aware of the sensitivities associated with conducting research of this nature, particularly in the aftermath of the Boston College Project (Belfast Project). ${ }^{6}$ As Robert W. White has commented, 'the Belfast project casts a long shadow over scholarship based on interviews with activists. Even if the questions asked are not controversial, respondents today are rightly concerned that their personal opinions might end up in the hands of the authorities. This may hinder scholarship for the foreseeable future but with time the controversy will fade. ${ }^{7}$

\section{Protections for interviewees}

Highly aware of the hostile environment in which this research was being conducted, throughout the research the author did not allow any interviewee to disclose any information of an illegal nature. The author began each interview by advising the interviewee to refrain from discussing anything illegal in relation to themselves or to any other individual or organisation. From its inception, this research was not concerned with operational activities and each interviewee was informed of this fact. As interviewees can attest, the questions which were posed regarded ideology, motivations, aspirations and strategy.

Interviewees spoke about their ideology and activism without straying into illegal territory, often commenting that they would not discuss certain themes or periods, some even refusing to express an opinion on the contemporary utility of political violence. The late Brendan Madden, a member of RSF in Galway, concluded his interview with the author in 2013 by stating 'there's other things that I'm not going to go into no matter whether you ask them or not. I'm giving you the broad view. There's other things that I'm going to die with, that I don't 
discuss anywhere. But I think you're doing grand. '8 Madden's strict adherence to discussing ideology and activism was the attitude adopted by all the interviewees. It became clear throughout the project that interviewees were internally weighting their concerns about giving an interview to a researcher, on the one hand, with what they often described as their 'duty' to promote the republican position and ideology, on the other hand. The author offered each interviewee a copy of their transcript to approve prior to its inclusion in this work; many requested their transcript, which they received.

As highlighted by J. Bowyer Bell, Richard English and Ed Moloney, among others, the Irish Republican Movement is authoritarian in nature, characterised by strict discipline. Stephen Hopkins has argued that 'a critical element of this perceived necessity for discipline was the requirement to maintain vigilance against the ever-present dangers of "informers" working on behalf of one or other branch of the British State's security forces (primarily either the Royal Ulster Constabulary Special Branch, or military intelligence). ${ }^{9}$ As demonstrated throughout this book, the Irish republican narrative and literature are littered with references to informers and agents, alongside stark warnings to remain vigilant about 'outsiders' and their motives for entering republican circles. Consequently, given the highly suspicious and insular nature of Irish republicanism, the author provided interviewees with full information about the project and transparent assurances about what information the author was collecting and how that information would be used for a book as well as articles in academic journals.

When the author became aware of the impact statement (it appeared online in August 2014 and the author's name was not on the statement), she immediately met with interviewees and explained face to face what had happened and clearly stated that Professor Tonge was no longer involved in the project. The author told interviewees that the research (which she began prior to formation of the research team) would continue but that interviewees had the right to withdraw unconditionally. A majority of the interviewees chose to remain involved, including prisoners in Maghaberry prison. Upon request, the author deleted interview recordings and destroyed transcripts, of individuals who withdrew from the project.

\section{Why did this happen?}

In July 2017 the author conducted an interview with Professor Jonathan Tonge regarding the impact statement which he had written, in an attempt to elicit an understanding of the reasons for the content of the statement. Academic work within the UK is assessed through the Research Excellence Framework (REF) which takes place approximately every seven years. The REF has put increasing emphasis on research with 'impact' and in the 2021 REF it is anticipated that impact will account for 25 per cent of the overall score attained by an 
institution. ${ }^{10}$ Within a context where funding bodies seek 'research with real world impact', academics are striving to emphasise the impact of their research 'beyond academia'. Tonge has emphasised that no information was ever passed to the security services and has stated that there was never any aim to pass on information:

My conscience is clear in terms of the intellectual design of the project in terms of what we were trying to seek research-wise. No information, no interviews were ever ever ever passed on to any other source ... it's important that misunderstandings don't arise from the project. The impact statement shouldn't jeopardise the whole research area. ${ }^{11}$

Regarding his motivations for writing the impact statement Tonge has stated:

I'd have been perfectly happy with this project just to have had a book at the end of it but the pressures of impact mean that you have to do more. Governments want value for money and they ultimately fund the research councils so you have to show that it's not just a book that will gather dust on the shelves. It has to have wider resonance. That's fine in a lot of cases but in more controversial ones you can see the dangers. ${ }^{12}$

Tonge has maintained that he was never approached by any state actors for information collected during the project and has stated that, had he been, he would not have handed over any material.

\section{Conclusion}

The impact statement, which was written by Tonge, is fundamentally at odds with the actual nature of the research project. At no point was any information passed to the security services. The author conducted all the interviews for this book and the recordings were securely stored in Belfast in the author's possession. Throughout the project, the author securely retained interviewee information in Belfast and transcripts were coded and anonymised. Tonge has stated 'I think I could name one person that was interviewed.' ${ }^{3}$ The situation outlined above resulted in some individuals stating that the interviews should be deleted. However, the research which the author has gathered over several years provides a valuable archive of oral history regarding non-mainstream republicanism. For a number of interviewees, this project is the only time that they have ever given an interview, and three of the interviewees for this work are now deceased.

While attending a book launch in Belfast in 2015 an interviewee approached the author to inquire about the status of the book. This interviewee's two sons were killed in 1993 in Lurgan after gunmen entered his home and shot them while they were sitting on their sofa. The interviewee said to the author that he had 'poured his heart out' in the interview and that he would be angry if it was for nothing and if no book materialised. The author has also been approached by other interviewees who have stated that it would be unfair to them if the book 
did not proceed. This issue has illustrated the very real sensitivities associated with conducting research in this field. The author has conducted the research to the highest ethical standards and has maintained the protection of all interviewees for this study.

\section{Notes}

1 Bowyer Bell, The Secret Army (1990), p. 451.

2 White, 'From state terrorism to petty harassment', p. 53.

3 Ibid., p. 51.

4 Snowball sampling is a research method in qualitative research where a research participant recommends a further research participant. This method is particularly valuable when researching groups or communities which are difficult to access.

5 J. Tonge, ESRC Funding Application, 2012.

6 Anthony McIntyre, 'The Belfast Project and the Boston College subpoena case', paper presented at the Oral History Network of Ireland (OHNI) Second Annual Conference in Ennis, Co. Clare, The Pensive Quill, 29 September 2012. http:// thepensivequill.am/2012/10/the-belfast-project-and-boston-college.html. Accessed 25 July 2018.

7 White, 'From state terrorism to petty harassment', p. 53.

8 Brendan Madden, interview with the author, Galway, 4 June 2013.

9 Hopkins, "The "informer", p. 2.

10 See www.ref.ac.uk/about/whatref/. Accessed 25 July 2018.

11 Jonathan Tonge, interview with the author, Liverpool, 4 July 2017.

12 Ibid.

13 Ibid. 